\title{
Study of disease-relevant polymorphisms in the TLR4 and TLR genes: A novel method applied to the analysis of the Portuguese population
}

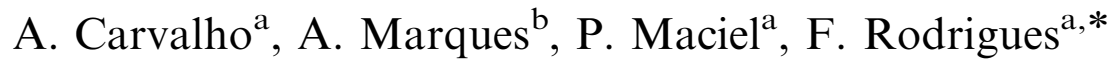 \\ ${ }^{\mathrm{a}}$ Life and Health Sciences Research Institute (ICVS), School of Health Sciences, University of Minho, Braga, Portugal \\ ${ }^{\mathrm{b}}$ Department of Immunohemotherapy, Hospital de São Marcos, Braga, Portugal
}

Received 28 November 2006; accepted 22 March 2007

Available online 30 March 2007

\begin{abstract}
Toll-like receptors (TLRs) are cellular receptors that mediate recognition of microbial challenges and the subsequent inflammatory response. Genetic variations within these inflammation-associated genes may alter host-pathogen defence mechanisms affecting susceptibility towards infectious diseases. Taking into account the significance of these genes, we developed a simple and rapid method based in the bi-directional PCR amplification of specific alleles (Bi-PASA) for genotyping known sequence variants in TLR4 (Asp299Gly and Thr399Ile) and TLR9 (T-1237C) genes. This method allows genotype determination in a single reaction and is amenable to largescale analysis. We used Bi-PASA to characterize the distribution of these polymorphisms in the Portuguese population. A total of 388 randomly selected blood donors of Portuguese origin (203 females and 185 males) were genotyped and allele frequencies were determined. Among the tested individuals, 11.1\% and 10.8\% were heterozygous for Asp299Gly and Thr399Ile, respectively. In what concerns the T-1237C variation in TLR9, the variant allele was present in $19.4 \%$ of the individuals tested. Besides confirming the usefulness of the Bi-PASA in polymorphism analysis, the data presented provide valuable information on $T L R$ polymorphisms in the Portuguese population that can be used to stratify risk patients with increased susceptibility to infection.
\end{abstract}

(C) 2007 Elsevier Ltd. All rights reserved.

Keywords: Bi-PASA; Toll-like receptor; Polymorphism

\section{Introduction}

The innate immune system is able to recognize conserved motifs in pathogens in which pattern recognition receptors, including toll-like receptors (TLRs), play an important role [1]. TLRs are a family of genetically conserved proteins identified as key components of the innate immune system, mediating recognition of microbial challenges and the subsequent inflammatory response [2]. The first of the currently known TLRs was described in 1997 as a human homolog of the Drosophila Toll protein, later designated TLR4 [3]. The complete TLR family allows the host to detect infection by most, if not all, types of microbial pathogens. Well characterized receptor-ligand pairs include TLR4 and lypopolysaccharide (LPS) [4,5], TLR5 and bacterial flagellin [6], TLR3 and viral double-stranded

\footnotetext{
*Corresponding author. Tel.: + 351253 604814; fax: + 351253604809.

E-mail address: frodrigues@ecsaude.uminho.pt (F. Rodrigues).
}

DNA [7], TLR9 and bacterial hypomethylated DNA [8] and TLR2, in association with TLR1 or TLR6, and a variety of cell wall components from gram-positive bacteria [9].

Cellular activation via TLRs triggers not only innate immune responses but also initiates adaptive immunity [10]. Due to the significance of TLRs in the immune system, genetic variations within these genes could have a major impact upon host immune response to pathogens and thus, an increased susceptibility to infection. Regarding TLRs, several polymorphisms are already largely studied and characterized concerning the phenotypical outcome, such as polymorphisms in TLR4 [A + 896G (SNP ID: rs4986790) and C+1196 T (SNP ID: rs4986791)]. These polymorphisms are located in the coding sequence resulting in amino acid exchanges: an aspartic acid for a glycine at position 299 (Asp299Gly) and a threonine for an isoleucine at position 399 (Thr399Ile), respectively, affecting the extracellular domain of this receptor. Others, such 
Table 1

Summary of association studies between $T L R 4 / T L R 9$ polymorphisms and infectious and inflammation-related diseases

\begin{tabular}{|c|c|c|c|c|c|c|c|}
\hline Reference & Association study & Patients $(n)$ & Controls $(n)$ & TLR SNP & & $\begin{array}{l}\text { Case vs. } \\
\text { control }(\%)\end{array}$ & $p$ value \\
\hline Arbour et al. [11] & $\begin{array}{l}\text { Hyporesponsiveness to } \\
\text { inhaled } \\
\text { lypopolysaccharide }\end{array}$ & 31 & 57 & TLR4 & Asp299Gly & 22.6 vs 5.8 & 0.029 \\
\hline & & & & & Thr399Ile & & \\
\hline Lorenz et al. [13] & Septic shock & 91 & 73 & & Asp299Gly & 5.5 vs 0 & 0.05 \\
\hline Lorenz et al. [32] & $\begin{array}{l}\text { Premature birth } \\
\text { associated to infection }\end{array}$ & 440 & 351 & & Asp299Gly & 23.8 vs 15.9 & 0.028 \\
\hline Agnese et al. [12] & $\begin{array}{l}\text { Gram-negative } \\
\text { infections }\end{array}$ & 77 & 39 & & $\begin{array}{l}\text { Thr399Ile } \\
\text { Asp299Gly }\end{array}$ & 18.0 vs 12.8 & 0.004 \\
\hline Tal et al. [31] & $\begin{array}{l}\text { Respiratory synctyal } \\
\text { virus infection }\end{array}$ & 99 & 82 & & $\begin{array}{l}\text { Thr399Ile } \\
\text { Asp299Gly }\end{array}$ & 20.2 vs 4.9 & 0.003 \\
\hline Edfeldt et al. [33] & $\begin{array}{l}\text { Myocardial infarction } \\
\text { associated to infection }\end{array}$ & 1213 & 1561 & & $\begin{array}{l}\text { Thr399Ile } \\
\text { Asp299Gly }\end{array}$ & 10.7 vs 7.9 & 0.004 \\
\hline Hawn et al. [34] & Legionnaire's disease & 108 & 510 & & $\begin{array}{l}\text { Thr399Ile } \\
\text { Asp299Gly } \\
\text { Thr399Ile }\end{array}$ & 2.5 vs 6.5 & 0.025 \\
\hline Rezazadeh et al. [35] & Brucellosis & 198 & 111 & & Asp299Gly & 33.6 vs 20.7 & $<0.0001$ \\
\hline $\begin{array}{l}\text { Mockenhaupt et al. } \\
{[36]}\end{array}$ & Severe malaria & 70 & 51 & & Thr399Ile & 24.1 vs 17.6 & $<0.05$ \\
\hline Lazarus et al. [17] & Asthma & 67 & 152 & TLR9 & $\mathrm{T}-1237 \mathrm{C}$ & 23.4 vs 14.5 & 0.042 \\
\hline Torok et al. [18] & Crohn's disease & 174 & 265 & & $\mathrm{~T}-1237 \mathrm{C}$ & 19.3 vs 11.9 & 0.0036 \\
\hline
\end{tabular}

as those concerning $T L R 9$, have just recently started to be characterized and their functional importance elucidated. Among these, the most studied is T-1237C (SNP ID: rs5743836), a polymorphism located within the putative promoter region that may influence transcriptional regulation of the TLR9 gene.

Arbour and colleagues were the first to describe that the two mutations affecting the extracellular domain of TLR4 protein at the 299 and 399 residues were associated with blunted physiological responses to inhaled lipopolysaccharide [11]. A large number of association studies followed and the most relevant are summarized in Table 1. Since their identification, these two mutations have been studied for their association with various infectious and inflammatory diseases. Specifically, a positive association of the Asp299Gly mutation with increased susceptibility to Gramnegative bacteremia and septic shock was found $[12,13]$. Interestingly however, no association between the Asp299Gly and/or Thr399Ile mutations was found for other diseases of infectious etiology, including candidiasis [14], tuberculosis [15] or meningococcal disease [16]. The variation $\mathrm{T}-1237 \mathrm{C}$ in the promoter region of $T L R 9$, on the other hand, has been shown to be associated with an increased risk for asthma [17] and preliminary data regarding a possible positive association with Crohn's disease was also reported [18]. Nevertheless, some studies also report no association between this polymorphism and susceptibility to systemic lupus erythematosus [19] and atopy [20].

Thus, assessment of polymorphisms in TLRs may have a potential clinically usefulness for risk stratification of patients possibly more vulnerable to infections. Some of the previously developed methods are, to a certain extent, attractive laboratory-tailored approaches for genotyping polymorphisms in $T L R$ genes, such as the real-time PCRbased method developed by Hamann et al. [21] or the single tube PCR reaction based on exonuclease degradation of allele-specific probes described by van Rijn et al. [22]. However, most of the genotyping techniques currently available are still either time-consuming and laborious or require expensive equipment [23-25]. In this sense, we adapted a simple and rapid method, allowing genotype determination in a single reaction based in the bidirectional PCR amplification of specific alleles (Bi-PASA) [26] in both the TLR4 (Asp299Gly, Thr399Ile) and TLR9 (T-1237C) genes, a methodology amenable to large scale analysis, using technology available in most scientific laboratories.

\section{Materials and methods}

Bi-PASA uses a combination of four primers, two outer primers (named $\mathrm{P}$ and $\mathrm{Q}$ ) and two inner allele-specific primers (termed $\mathrm{M}$ and $\mathrm{W}$ ). The inner primers are characterized by containing a 10 -nucleotide $\mathrm{G}+\mathrm{C}$-rich $5^{\prime}$ tail, which prevents "megapriming" and enhances the efficiency of amplification. Depending on the genotype, Bi-PASA produces two or three overlapping fragments. PQ is always produced and serves as a positive control. PW and MQ are present in a heterozygote individual, but PW is only produced in wild-type homozygote and MQ only in 
homozygous mutant samples (Fig. 1). Primers for BiPASA were designed following the guidelines proposed by Liu et al. [26], taking into account both the melting temperature of both the primers and the largest PCR segment (PQ). The primers used in this study are shown in Table 2. The Bi-PASA methodology was optimized using DNA samples from individuals with known genotype for the polymorphisms being studied (Fig. 1(B)-(D)). These samples were previously genotyped by Berghöfer et al. and Hamann et al., using real-time PCR-based methodologies and confirmed by direct sequencing [20,21].

DNA was isolated from whole blood samples using the salting-out procedure described by Miller et al. [27] and PCR amplification was performed in a $20 \mu \mathrm{l}$ volume that included autoclaved ultra-filtered water, PCR buffer $(1.6 \times), \quad$ dNTP mixture $(200 \mu \mathrm{M}$ each $)$, primers (0.05-0.4 $\mu \mathrm{M}$ each; for details see Table 2), Taq DNA polymerase $(1 \mathrm{U} / 20 \mu \mathrm{l})$ and approximately $50 \mathrm{ng}$ genomic DNA templates. PCR cycling conditions included 35 cycles of $15 \mathrm{~s}$ at $94{ }^{\circ} \mathrm{C}, 30 \mathrm{~s}$ at $57^{\circ} \mathrm{C}$, and $45 \mathrm{~s}$ at $65^{\circ} \mathrm{C}$, after a 10-min initial period of DNA denaturation and enzyme activation at $94{ }^{\circ} \mathrm{C}$. The amplified fragments had sizes readily distinguishable by electrophoresis through a $2 \%$ agarose gel. The results obtained for the genotype of the Portuguese population by Bi-PASA were further validated by sequencing analysis of 10 randomly selected samples (data not shown).

\section{Results and discussion}

After written informed consent was obtained from each volunteer, a total of 388 randomly selected blood donors of Portuguese origin (203 females and 185 males) were genotyped using Bi-PASA. Among the tested individuals, $43 / 388(11.1 \%)$ and $42 / 388(10.8 \%)$ were heterozygous for Asp299Gly and Thr399Ile polymorphisms, respectively. None of the individuals showed a homozygous TLR4 polymorphism. In what concerns the $\mathrm{T}-1237 \mathrm{C}$ variation in TLR9, 67/388 (17.3\%) were heterozygous and 8/388 $(2.1 \%)$ were homozygous for this polymorphism. Based

A

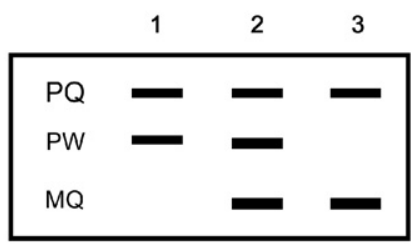

1 - wild type homozygote

2 - heterozygote

3 - mutant homozygote

B

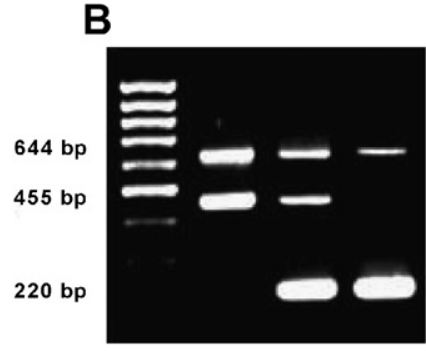

C

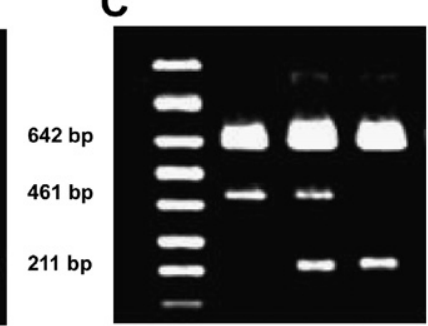

D

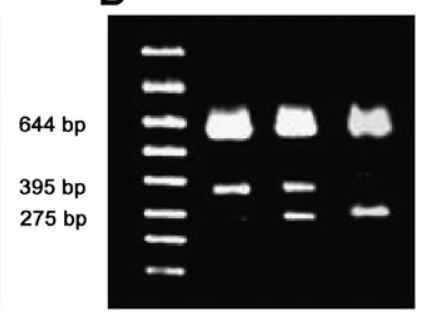

Fig. 1. Predicted band pattern obtained with Bi-PASA genotyping (A). Agarose gel electrophoresis showing results of Bi-PASA genotyping for Asp299Gly (B), Thr399Ile (C) and T-1237C (D).

Table 2

Bi-PASA primers used in this study

\begin{tabular}{|c|c|c|c|}
\hline Gene & Polymorphism & Primer & $\begin{array}{l}\text { Primer final concentration } \\
(\mu \mathrm{M})\end{array}$ \\
\hline \multirow[t]{5}{*}{ TLR4 } & Asp299Gly & P: 5'-AGAACTTAATGTGGCTCACAAT-3' & 0.1 \\
\hline & & W: $5^{\prime}$-gggecgggggTACTACCTCGATGG-3' & 0.4 \\
\hline & & M: 5'-ggcggcggggTTAAATAAGTCAATAATAT-3' & 0.4 \\
\hline & Thr399Ile & P: 5'-CTGGCTGGTTTAGAAGTCCA-3' & 0.1 \\
\hline & & M: 5'-ggcggcggggTGATTTTGGGACAAT-3' & 0.1 \\
\hline \multirow[t]{4}{*}{ TLR9 } & $\mathrm{T}-1237 \mathrm{C}$ & P: 5'-TCATTCAGCCTTCACTCAGA-3' & 0.4 \\
\hline & & Q: 5'-CACATTCAGCCCCTAGAGGG-3' & 0.4 \\
\hline & & W: 5'-ggcggcggggGTGCTGTTCCCTCTGCCTGA-3' & 0.05 \\
\hline & & M: 5'-gggccgggggATGAGACTTGGGGGAGTTTC-3' & 0.05 \\
\hline
\end{tabular}


Table 3

Allele frequencies of each $T L R$ polymorphism in distinct ethnic populations [data from Entrez SNP database (http://www.ncbi.nlm.nih.gov/entrez/ query.fcgi?CMD $=$ search\&DB $=$ snp) in November, 2006] and in our study in the Portuguese population

\begin{tabular}{|c|c|c|c|c|c|c|}
\hline \multirow[t]{2}{*}{ TLR SNP } & & \multicolumn{5}{|c|}{ Allele frequencies } \\
\hline & & This study & European & Asian & African American & Sub-Saharan African \\
\hline \multirow{2}{*}{ Asp299Gly } & $\mathrm{A}$ & 0.889 & 0.967 & 1.000 & 0.848 & 0.967 \\
\hline & G & 0.111 & 0.033 & 0 & 0.152 & 0.033 \\
\hline \multirow[t]{2}{*}{ Thr399Ile } & $\mathrm{C}$ & 0.892 & 0.967 & 1.000 & $\mathrm{n} / \mathrm{a}$ & 1.000 \\
\hline & $\mathrm{T}$ & 0.108 & 0.033 & 0 & & 0 \\
\hline \multirow[t]{2}{*}{$\mathrm{T}-1237 \mathrm{C}$} & $\mathrm{C}$ & 0.806 & 0.841 & 0.974 & 0.750 & $\mathrm{n} / \mathrm{a}$ \\
\hline & $\mathrm{T}$ & 0.194 & 0.159 & 0.026 & 0.250 & \\
\hline
\end{tabular}

$\mathrm{n} / \mathrm{a}-$ not available.

on the control samples of a large number of published studies [28], the two TLR4 polymorphisms, Asp299Gly and Thr399Ile, are known to be present at an overall allele frequency of $6.4 \pm 2.8$ (range, $0-19.6 ; n=38$ studies) and $7.2 \pm 3.8$ (range, $0-13, n=11$ ), respectively. However, reports of differences in the frequencies of these two polymorphisms among different ethnic groups have been published [15,29]. In fact, considering the data currently available on the Entrez SNP database (Table 3), the frequency of TLR4 Asp299Gly polymorphism is much higher in African Americans than in Europeans and subSaharan Africans, in contrast to Asians, where this particular polymorphism does not seem to occur. The overall frequencies of Thr399Ile are similar to that of Asp299Gly, although no data is available for African Americans. African Americans also display a higher frequency of the TLR 9 polymorphism than Europeans and Asians. Comparing with our results, we can observe that TLR4 Asp299Gly and Thr399Ile allele frequencies in the Portuguese population are higher than those described for the European population characterized in the Entrez database, although similar to those of controls published in association studies using European populations. Concerning TLR9, the frequency of $\mathrm{T}-1237 \mathrm{C}$ in the Portuguese population is similar to the one presented in the database for the European population. Distributions of both TLR4 and $T L R 9$ genotypes did not deviate from those predicted by the Hardy-Weinberg equilibrium (Asp299Gly, $p=0.388$; Thr399Ile, $p=0.410 ; \mathrm{T}-1237 \mathrm{C}, p=0.58)$. In addition and as expected, both TLR4 polymorphisms are in total linkage disequilibrium $\left(D^{\prime}=1.000\right)$. In fact, cosegregation among these two mutations has also been largely stated [13,30,31].

In conclusion, the data herein presented provides valuable information on $T L R$ polymorphisms in the Portuguese population that can be used in future studies to stratify patients regarding susceptibility to infection. Our results clearly show that Bi-PASA is a valuable methodology for genotyping studies. In addition, this method can easily be applied in studies of large populations, and further applied for the study of other polymorphisms, as it is a cost-effective technique, where in a single reaction the genotype of the individuals can be determined.

\section{Acknowledgements}

We are grateful to Dr. Hamann, L. (Institute for Microbiology and Hygiene, Charite Medical Center, Humboldt University, Berlin, Germany) and Dr. Berghöfer, B. (Institute for Clinical Immunology and Transfusion Medicine, Justus-Liebig University, Giessen, Germany) who kindly provided the DNA samples used to optimize the Bi-PASA technique. Carvalho A. was financially supported by a fellowship from Fundação para a Ciência e Tecnologia, Portugal (contract SFRH/BD/11837/2003). This study was supported by Fundação para a Ciência e Tecnologia, Portugal (POCI/SAU-ESP/61080/2004).

\section{References}

[1] Medzhitov R, Janeway Jr. C. Innate immune recognition: mechanisms and pathways. Immunol Rev 2000;173:89-97.

[2] Medzhitov R, Janeway Jr. C. The Toll receptor family and microbial recognition. Trends Microbiol 2000;8:452-6.

[3] Medzhitov R, Preston-Hurlburt P, Janeway Jr. CA. A human homologue of the Drosophila Toll protein signals activation of adaptive immunity. Nature 1997;388:394-7.

[4] Poltorak A, He X, Smirnova I, Liu MY, Van HC, Du X, et al. Defective LPS signaling in $\mathrm{C} 3 \mathrm{H} / \mathrm{HeJ}$ and $\mathrm{C} 57 \mathrm{BL} / 10 \mathrm{ScCr}$ mice: mutations in Tlr4 gene. Science 1998;282:2085-8.

[5] Hoshino K, Takeuchi O, Kawai T, Sanjo H, Ogawa T, Takeda Y, et al. Cutting edge: Toll-like receptor 4 (TLR4)-deficient mice are hyporesponsive to lipopolysaccharide: evidence for TLR4 as the Lps gene product. J Immunol 1999;162:3749-52.

[6] Hayashi F, Smith KD, Ozinsky A, Hawn TR, Yi EC, Goodlett DR, et al. The innate immune response to bacterial flagellin is mediated by Toll-like receptor 5. Nature 2001;410:1099-103.

[7] Alexopoulou L, Holt AC, Medzhitov R, Flavell RA. Recognition of double-stranded RNA and activation of NF-kappaB by Toll-like receptor 3. Nature 2001;413:732-8.

[8] Hemmi H, Takeuchi O, Kawai T, Kaisho T, Sato S, Sanjo H. A Tolllike receptor recognizes bacterial DNA. Nature 2000;408:740-5.

[9] Kirschning CJ, Schumann RR. TLR2: cellular sensor for microbial and endogenous molecular patterns. Curr Top Microbiol Immunol 2002;270:121-44

[10] Akira S, Takeda K, Kaisho T. Toll-like receptors: critical proteins linking innate and acquired immunity. Nat Immunol 2001;2:675-80. 
[11] Arbour NC, Lorenz E, Schutte BC, Zabner J, Kline JN, Jones M, et al. TLR4 mutations are associated with endotoxin hyporesponsiveness in humans. Nat Genet 2000;25:187-91.

[12] Agnese DM, Calvano JE, Hahm SJ, Coyle SM, Corbett SA, Calvano $\mathrm{SE}$, et al. Human toll-like receptor 4 mutations but not CD14 polymorphisms are associated with an increased risk of gramnegative infections. J Infect Dis 2002;186:1522-5.

[13] Lorenz E, Mira JP, Frees KL, Schwartz DA. Relevance of mutations in the TLR4 receptor in patients with gram-negative septic shock. Arch Intern Med 2002;162:1028-32.

[14] Morre SA, Murillo LS, Spaargaren J, Fennema HS, Pena AS. Role of the toll-like receptor 4 Asp299Gly polymorphism in susceptibility to Candida albicans infection. J Infect Dis 2002;186:1377-9.

[15] Newport MJ, Allen A, Awomoyi AA, Dunstan SJ, McKinney E, Marchant A, et al. The toll-like receptor 4 Asp299Gly variant: no influence on LPS responsiveness or susceptibility to pulmonary tuberculosis in The Gambia. Tuberculosis (Edinb) 2004;84:347-52.

[16] Read RC, Pullin J, Gregory S, Borrow R, Kaczmarski EB, di Giovine FS, et al. A functional polymorphism of toll-like receptor 4 is not associated with likelihood or severity of meningococcal disease. J Infect Dis 2001;184:640-2.

[17] Lazarus R, Klimecki WT, Raby BA, Vercelli D, Palmer LJ, Kwiatkowski DJ, et al. Single-nucleotide polymorphisms in the Toll-like receptor 9 gene (TLR9): frequencies, pairwise linkage disequilibrium, and haplotypes in three U.S. ethnic groups and exploratory case-control disease association studies. Genomics 2003;81:85-91.

[18] Torok HP, Glas J, Tonenchi L, Bruennler G, Folwaczny M, Folwaczny C. Crohn's disease is associated with a toll-like receptor-9 polymorphism. Gastroenterology 2004;127:365-6.

[19] De Jager P, Richardson A, Vyse T, Rioux J. Genetic variation in Toll-like receptor 9 and susceptibility to systemic lupus erythematosus. Arthritis Rheum 2006;54:1279-82.

[20] Berghofer B, Frommer T, Konig IR, Ziegler A, Chakraborty T, Bein $\mathrm{G}$, et al. Common human Toll-like receptor 9 polymorphisms and haplotypes: association with atopy and functional relevance. Clin Exp Allergy 2005;35:1147-54.

[21] Hamann L, Hamprecht A, Gomma A, Schumann RR. Rapid and inexpensive real-time PCR for genotyping functional polymorphisms within the Toll-like receptor -2 , -4 , and -9 genes. J Immunol Methods 2004;285:281-91.

[22] van Rijn BB, Roest M, Franx A, Bruinse HW, Voorbij HA. Single step high-throughput determination of Toll-like receptor 4 polymorphisms. J Immunol Methods 2004;289:81-7.

[23] Schmitt C, Humeny A, Becker CM, Brune K, Pahl A. Polymorphisms of TLR4: rapid genotyping and reduced response to lipo- polysaccharide of TLR4 mutant alleles. Clin Chem 2002;48: 1661-7.

[24] Lorenz E, Frees KL, Schwartz DA. Determination of the TLR4 genotype using allele-specific PCR. Biotechniques 2001;31:22-4.

[25] Heesen M, Wessiepe M, Kunz D, Vasickova K, Blomeke B. Rapid and reliable genotyping for the Toll-like receptor 4 A896G polymorphism using fluorescence-labeled hybridization probes in a real-time polymerase chain reaction assay. Clin Chim Acta 2003;333:47-9.

[26] Liu Q, Thorland EC, Heit JA, Sommer SS. Overlapping PCR for bidirectional PCR amplification of specific alleles: a rapid one-tube method for simultaneously differentiating homozygotes and heterozygotes. Genome Res 1997;7:389-98.

[27] Miller SA, Dykes DD, Polesky HF. A simple salting out procedure for extracting DNA from human nucleated cells. Nucleic Acids Res 1988; 16:1215.

[28] Vogel SN, Awomoyi AA, Rallabhandi P, Medvedev AE. Mutations in TLR4 signaling that lead to increased susceptibility to infection in humans: an overview. J Endotoxin Res 2005;11:333-9.

[29] Smirnova I, Hamblin MT, McBride C, Beutler B, Di RA. Excess of rare amino acid polymorphisms in the Toll-like receptor 4 in humans. Genetics 2001;158:1657-64.

[30] Hartel C, Finas D, Ahrens P, Kattner E, Schaible T, Muller D, et al Polymorphisms of genes involved in innate immunity: association with preterm delivery. Mol Hum Reprod 2004;10:911-5.

[31] Tal G, Mandelberg A, Dalal I, Cesar K, Somekh E, Tal A, et al Association between common Toll-like receptor 4 mutations and severe respiratory syncytial virus disease. J Infect Dis 2004;189: 2057-63.

[32] Lorenz E, Hallman M, Marttila R, Haataja R, Schwartz DA. Association between the Asp299Gly polymorphisms in the Toll-like receptor 4 and premature births in the Finnish population. Pediatr Res 2002;52:373-6.

[33] Edfeldt K, Bennet AM, Eriksson P, Frostegard J, Wiman B, Hamsten A, et al. Association of hypo-responsive toll-like receptor 4 variants with risk of myocardial infarction. Eur Heart J 2004;25:1447-53.

[34] Hawn TR, Verbon A, Janer M, Zhao LP, Beutler B, Aderem A. Tolllike receptor 4 polymorphisms are associated with resistance to Legionnaires' disease. Proc Natl Acad Sci USA 2005;102:2487-9.

[35] Rezazadeh M, Hajilooi M, Rafiei A, Haidari M, Nikoopour E, Kerammat F, et al. TLR4 polymorphism in Iranian patients with brucellosis. J Infect 2006;53(3):206-10.

[36] Mockenhaupt FP, Cramer JP, Hamann L, Stegemann MS, Eckert J, Oh NR, et al. Toll-like receptor (TLR) polymorphisms in African children: Common TLR-4 variants predispose to severe malaria. Proc Natl Acad Sci USA 2006;103:177-82. 